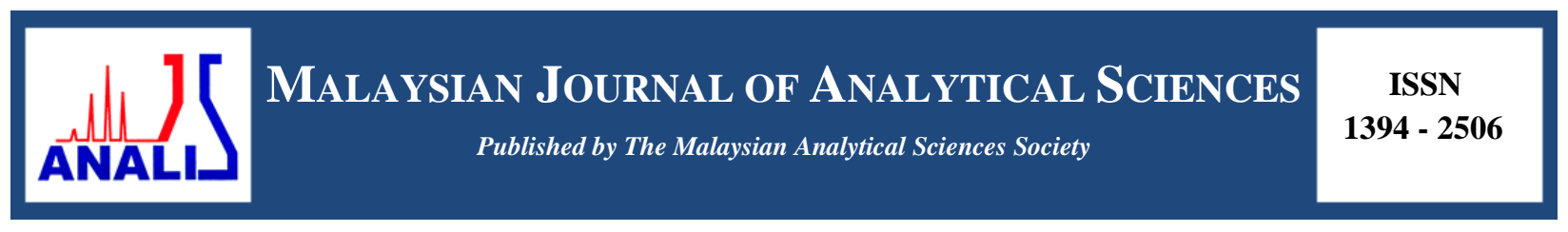

\title{
ANTIOXIDANT ACTIVITY, COLOUR AND MINERAL CONTENT OF HERBAL TEA PREPARED FROM Cosmos caudatus LEAVES AT DIFFERENT MATURITY STAGES
}

\author{
(Aktiviti Antioksida, Warna dan Kandungan Mineral di dalam Teh Herba daripada Daun \\ Cosmos caudatus pada Peringkat Kematangan yang Berbeza) \\ Dian Nashiela Fatanah ${ }^{1}$, Noriham Abdullah ${ }^{1,2}$, Nooraain Hashim ${ }^{1}$, Azizah Abd Hamid ${ }^{3}$ \\ ${ }^{1}$ Department of Food Science and Technology, Faculty of Applied Sciences \\ ${ }^{2}$ Malaysia Institute of Transportation (MITRANS) \\ Universiti Teknologi MARA, 40450 Shah Alam, Selangor, Malaysia \\ ${ }^{3}$ Department of Food Science, Faculty of Food Science and Technology, \\ Universiti Putra Malaysia, 43400 UPM Serdang, Selangor, Malaysia \\ *Corresponding author: noriham985@salam.uitm.edu.my
}

Received: 24 February 2015; Accepted: 27 October 2015

\begin{abstract}
In recent years, increasing consumption of herbal tea is a worldwide trend because of their refreshing taste, positive potential health effect, convenience, abundant resources and also cheaper in price. However, different maturity stages of plants being used as raw material could affect the antioxidant activity, colour and mineral content in herbal tea. Thus, this present study was aimed at determining antioxidant activity, colour and mineral content of herbal tea prepared from Cosmos caudatus (C. caudatus) leaves at three different maturity stages namely young, mature and old. All prepared herbal tea were analysed for total phenolic content (TPC), total flavonoid content (TFC), ferric reducing antioxidant power (FRAP), 2-2-diphenyl-1-picrylhydrazyl (DPPH) radical scavenging assay, colour and mineral content. The results demonstrated that herbal tea prepared from young leaves had strong $(\mathrm{p}<0.05)$ antioxidant activity compared to mature and old leaves for all assays tested. Pearson's correlation coefficient also revealed that TPC and TFC exhibited a strong positive correlation with reducing power but negatively correlated with DPPH scavenging activity indicating that these compounds are major contributors to the antioxidant activity. In fact, the darker ( $\mathrm{p}<$ 0.05) colour of $C$. caudatus herbal tea prepared from young leaves relates to their higher antioxidant activity as compared to mature and old leaves. However, $C$. caudatus herbal tea prepared from old leaves showed significantly higher in mineral content compared to mature and young leaves. Hence, it can be concluded that, as maturity increased, antioxidant activity and colour in C. caudatus herbal tea decreased and vice-versa for mineral content.
\end{abstract}

Keywords: herbal tea, Cosmos caudatus, maturity, antioxidant activity, colour, mineral content

\begin{abstract}
Abstrak
Pada masa kini, peningkatan pengambilan teh herba menjadi ikutan terkini di seluruh dunia kerana rasa yang menyegarkan, mempunyai potensi yang positif terhadap kesihatan, sumber yang mudah didapati dan harga yang murah. Walaubagaimanapun, penggunaan sumber bahan mentah daripada tumbuh-tumbuhan pada peringkat kematangan yang berbeza mempengaruhi aktiviti antioksida, warna dan kandungan mineral di dalam teh herba. Oleh itu, kajian ini bertujuan untuk menentukan aktiviti antioksida, warna dan kandungan mineral di dalam teh herba yang dihasilkan daripada daun Cosmos caudatus (C. caudatus) pada tiga peringkat kematangan iaitu daun muda, matang dan tua. Semua sampel teh herba telah dianalisa untuk menentukan jumlah kandungan fenol (TPC), jumlah kandungan flavonoid (TFC), ujian penurunan ferik (FRAP), pemerangkapan radikal bebas 2-2difenil-1-1 pikrilhidrazil (DPPH), warna dan kandungan mineral. Keputusan menunjukkan bahawa, teh herba dihasilkan daripada daun muda mempunyai aktiviti antioksida yang tinggi $(\mathrm{p}<0.05)$ berbanding dengan daun matang dan tua untuk semua asai diuji.
\end{abstract}


Pekali korelasi Pearson juga menunjukkan bahawa TPC dan TFC mempunyai korelasi positif yang kuat dengan pengurangan kuasa tetapi mempunyai korelasi negatif yang kuat terhadap aktiviti pemerangkapan DPPH, menunjukkan bahawa sebatiansebatian ini merupakan penyumbang utama kepada aktiviti antioksida. Malah, warna teh herba yang dihasilkan daripada daun $C$. caudatus muda yang lebih gelap $(\mathrm{p}<0.05)$, menunjukkan tahap aktiviti antioksida yang tinggi berbanding daun matang dan tua. Walaubagaimanapun, teh herba yang dihasilkan daripada daun $C$. caudatus tua menunjukkan kandungan mineral yang tinggi berbanding daun matang dan muda. Kesimpulannya, semakin meningkat kematangan daun, aktiviti antioksida dan warna semakin berkurang dan adalah sebaliknya bagi kandungan mineral.

Kata kunci: teh herba, Cosmos caudatus, kematangan, aktiviti antioksida, warna, kandungan mineral

\section{Introduction}

Increasing consumption of herbal tea is a worldwide trend because people believed that supplementation of human diet with herbal provides beneficial effects to their health [1]. Herbal tea has been used for health care and diseases prevention for thousands of years in many countries [2]. Moreover, numerous epidemiological studies link herbal tea consumption to a reduction in cardiovascular diseases, cholesterol levels, diabetes, arthritis, osteoporosis and dental carries [3]. Besides giving negligible side effects and mild in action, herbal tea is easy to prepare, richer in resources and cheaper in price [4]. Herbal tea can be prepared with fresh or dried flowers, leaves, seeds or roots, generally by pouring boiling water over the plant parts and letting them to steep for a few minutes [5]. In Malaysia, there are abundant herbal teas produced by Small Medium Enterprise (SME) industry such as misai kucing (Orthosiphon stamineus) tea, kacip fatimah (Labisia pumila) tea, sabung nyawa (Gynura procumbens) tea, kaca beling (Strobilanthes crispa) tea, ginger (Zingiber officinale) tea and lemongrass (Cymbopogon) tea.

Cosmos caudatus (C. caudatus) or commonly known as ulam raja by the Malay society has been developed in tea form because of its potential health-promoting properties. C. caudatus is used traditionally to reduce body heat, improving blood circulation, as an anti-aging agent, strengthening bone marrow (because of high calcium content), to treat infection associated with pathogenic microorganisms and to promote fresh breath [6]. These beneficial health properties have been attributed to the antioxidant content in $C$. caudatus plant particularly a number of proanthocyanidins that exists as dimers through hexamers, quercetin glycosides, chlorogenic, neo-chlorogenic acid and (+)-catechin [7]. With extremely high antioxidant activity, C. caudatus is believed to reduce oxidative stress because these compounds may have direct contribution in the defence against oxidative stress and could be considered to be active metabolites involved in the antioxidant activity in herbs [8]. From the nutritional point of view, other valuable components in herbs like minerals are also major contribution of health properties in $C$. caudatus plant. In fact, it has been established that deficiency of several minerals might induced phenolics and flavonoids content accumulation and supplementation of some minerals might promote antioxidant content [9]. However, maturation stages constitute an important factor in influencing antioxidant activity, chemical composition and mineral content of the $C$. caudatus plant. Usage of young leaves for herbal tea preparation might cause yield losses due to premature stages but usage of mature or old leaves could also possibly results in leaves senescence.

Therefore, this present study is designed to determine antioxidant activity, colour and mineral content of herbal tea prepared from $C$. caudatus leaves at different maturity stages since to the best of our knowledge antioxidant activity, colour and mineral content of these types of tea have not yet been reported.

\section{Chemicals}

\section{Materials and Methods}

Folin-Ciocalteu reagent, sodium carbonate $\left(\mathrm{Na}_{2} \mathrm{CO}_{3}\right)$, sodium nitrite $\left(\mathrm{NaNO}_{2}\right)$, aluminium chloride $\left(\mathrm{AlCl}_{3}\right)$, ferric chloride $\left(\mathrm{FeCl}_{3}\right)$ and sodium hydroxide $(\mathrm{NaOH})$, concentrated nitric acid $\left(\mathrm{HNO}_{3}\right)$, hydrogen peroxide $\left(\mathrm{H}_{2} \mathrm{O}_{2}\right)$ and Inductively Coupled Plasma (ICP) multi-element standard solution IV were purchased from Merck, Germany. Gallic acid, quercetin, trolox, 2-4-6-tripyridyl-s-triazine (TPTZ), 2-2-diphenyl-1-picrylhydrazyl (DPPH) and ascorbic acid were supplied by Sigma-Aldrich Chemie, Germany. Sodium acetate was purchased from R \& M Chemicals, U.K while glacial acetic acid was purchased from Friendemann Schmidt Chemicals, U.K. 


\section{Raw material collection and selection}

The fresh leaves of 8-week-old C. caudatus plant were collected from Durian Tunggal, Malacca, Malaysia. The leaves were divided into 3 groups, classified as young leaves, mature leaves and old leaves as shown in Figure 1. The 8-week-old C. caudatus plant was selected based on the previous findings from Mediani et al. [8] where they reported that 8-week-old plant consist higher antioxidant activity compared to 10 and 12-week-old C. caudatus plant. Young leaves were selected from the first four tiers where the leaves are still tender, newly emerged and not attaining full expansion. Mature leaves are located at the middle part of $C$. caudatus plant where the leaves are fully developed while old leaves are located at the lower part of the plant and the leaves had showed initial sign of senescence. Mature leaves were selected between the fifth to eighth tiers and old leaves were selected starting from ninth tier and above.

\section{Sample preparation}

Each stage of $C$. caudatus leaves was prepared according to the normal procedure of herbal tea preparation by Small Medium Enterprise (SME) industry in Malaysia. The leaves at different maturity stages were dried at $50{ }^{\circ} \mathrm{C}$ for 8 hours in cabinet dryer until constant weight. C. caudatus herbal tea powder was prepared according to method described by Gião et al. [10] with some modifications. The dried leaves were ground using centrifugal mill, which were then sieved into 1 to $2 \mathrm{~mm}$ mesh size. Two grams of ground leaves were collected and packed in a sachet of tea bag. The tea bag of $C$. caudatus herbal teas with different maturity stages were infused in $200 \mathrm{~mL}$ boiling distilled water for 3 minutes according to method as suggested by Horžić et al. [3]. The infused herbal teas were filtered through a Whatman filter paper No. 41 prior to further analyses.

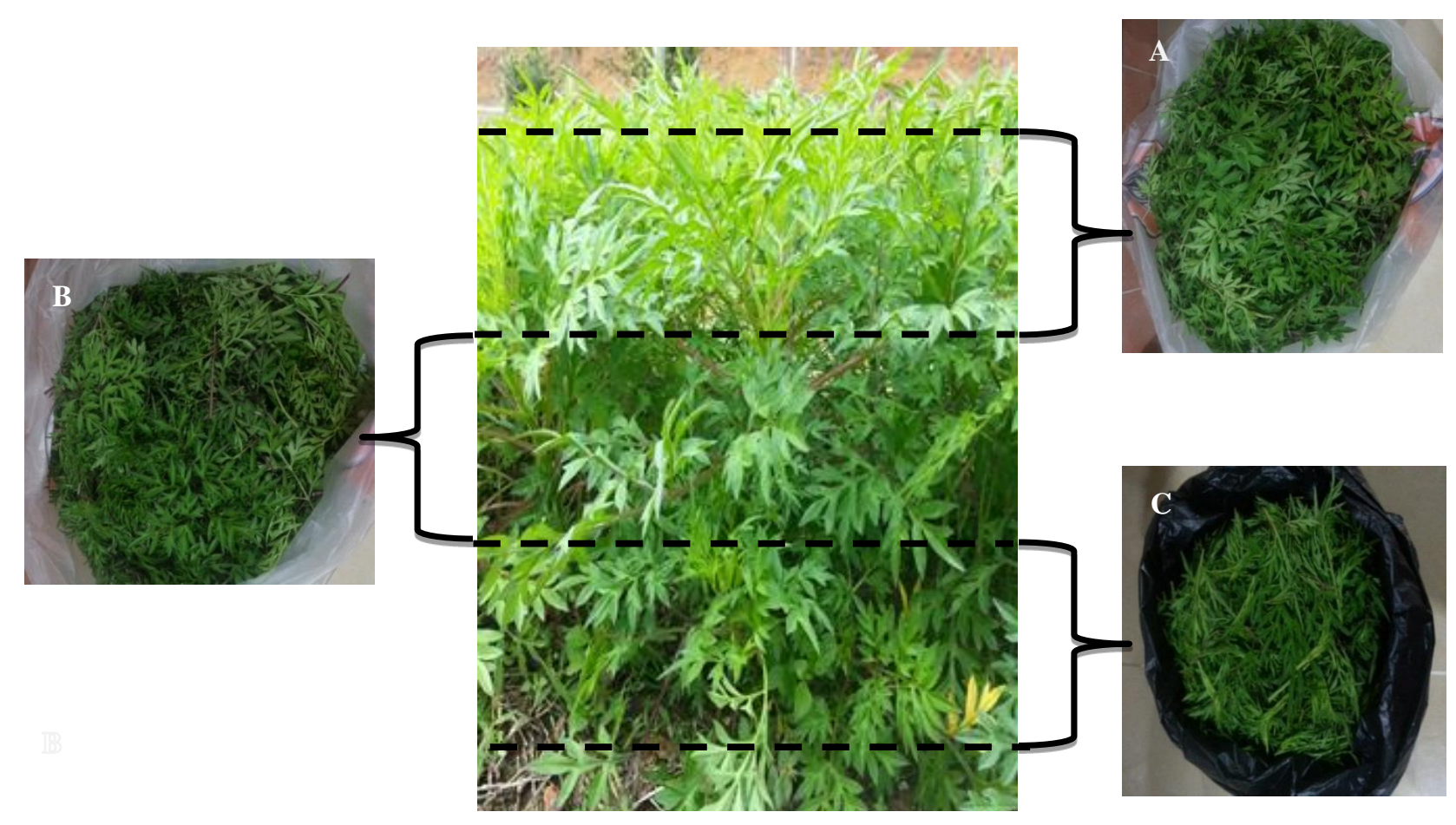

Figure 1. Selection of 8-week-old C. caudatus leaves based on maturity. (A) Young leaves (B) Mature leaves (C) Old leaves 


\section{Antioxidant content and antioxidant activity: Total phenolic content (TPC)}

The total phenolic content in herbal tea sample was determined by using the Folin-Ciocalteu assay [11]. Accurately, $0.5 \mathrm{~mL}$ Folin-Ciocalteu reagent, $1.5 \mathrm{~mL} 7.5 \%$ sodium carbonate and $7.9 \mathrm{~mL}$ distilled water were introduced in a test tube containing $0.1 \mathrm{~mL}$ sample/standard. The solution was mixed thoroughly and allowed to stand for 2 hours in a dark place. The absorbance at $765 \mathrm{~nm}$ was read by using UV-VIS Spectrophotometer (Helios Zeta, Thermo Fisher Scientific, USA). The TPC of herbal tea sample was expressed as $\mathrm{mg}$ of gallic acid equivalents (mg GAE)/ml of tea sample.

\section{Total flavonoid content (TFC)}

The total flavonoid content was analysed according to method as described by Singh et al. [12]. Accurately $1 \mathrm{~mL}$ of sample/standard was diluted with $4 \mathrm{~mL}$ distilled water then $0.3 \mathrm{~mL} 5 \%$ sodium nitrate solution and $0.3 \mathrm{~mL} 10 \%$ aluminium chloride were added. The mixture was kept for 5 minutes. Then, $2 \mathrm{~mL}$ of $1 \mathrm{M}$ sodium hydroxide were added to the mixture and the mixture was vortexed thoroughly. The absorbance was measured at $510 \mathrm{~nm}$ using Helios Zeta UV-VIS Spectrophotometer. This was calculated as mg of quercetin equivalents (mg QE)/ml of tea sample.

\section{Ferric reducing antioxidant power (FRAP)}

The FRAP assay was carried out by the method of Deetae et al. [13]. FRAP reagent was freshly prepared by mixing $300 \mathrm{mM}$ acetate and glacial acetic acid buffer (pH 3.6), $20 \mathrm{mM}$ ferric chloride and $10 \mathrm{mM}$ TPTZ was made to 40 $\mathrm{mM} \mathrm{HCl}$ at a ratio of 10:1:1. Briefly, $0.1 \mathrm{~mL}$ sample/standard was mixed with $3 \mathrm{~mL}$ FRAP reagent and $3 \mathrm{~mL}$ distilled water. The mixture was incubated in the dark place at $37{ }^{\circ} \mathrm{C}$ for 8 minutes and the absorbance at $595 \mathrm{~nm}$ was then read using Helios Zeta UV-VIS Spectrophotometer. The total antioxidant activity of samples were determined against a standard of known FRAP value and was expressed as $\mu \mathrm{M}$ of trolox equivalent $(\mu \mathrm{M}$ TE)/ml of tea sample.

\section{2-2-diphenyl-1-picrylhydrazyl (DPPH) radical scavenging assay}

The DPPH assay was performed according to procedure as described by Nuengchamnong and Ingkaninan [14]. Accurately, $0.1 \mathrm{~mL}$ sample/standard was mixed with $2.9 \mathrm{~mL}$ of $0.05 \mathrm{mM} \mathrm{DPPH}$ in methanol and incubated in the dark at room temperature for 30 minutes. The absorbance of the sample/standard was measured using Helios Zeta UV-VIS Spectrophotometer at $515 \mathrm{~nm}$ where methanol was used as blank.

\section{Colour}

The colour of $C$. caudatus herbal tea was determined using a CR-400 Chroma Meter (Konica Minolta, Minolta Co., Osaka, Japan) according to Marete et al. [15] method. The Hunter L, a, b Colour Scale was used with L*, a*, b*, C and $\mathrm{h}^{\circ}$ axes expressing the lightness, redness-greenness, blueness-yellowness, chroma and hue angle respectively. Hue angle is defined by as a colour wheel with red-purple at an angle of $0^{\circ}$, yellow at $90^{\circ}$, bluish-green at $180^{\circ}$ and blue at $270^{\circ}$.

\section{Mineral content}

The mineral content determination was performed based on Pytlakowska [16] procedure. In determining the concentration of selected elements ( $\mathrm{Ag}, \mathrm{Al}, \mathrm{Ba}, \mathrm{Ca}, \mathrm{Cd}, \mathrm{Cr}, \mathrm{Cu}, \mathrm{Fe}, \mathrm{K}, \mathrm{Mg}, \mathrm{Mn}, \mathrm{Na}, \mathrm{Pb}$ and $\mathrm{Zn}$ ) in herbal tea, the prepared infused herbal tea was evaporated to near dryness. To the solid residue, $5 \mathrm{~mL}$ of concentrated $\mathrm{HNO}_{3}$ solution and $5 \mathrm{~mL}$ of $30 \% \mathrm{H}_{2} \mathrm{O}_{2}$ solution were added, and sample was again evaporated to near dryness. Then, the residue was dissolved in $10 \mathrm{~mL}$ hot water, filtered and filled up to $25 \mathrm{~mL}$ with deionized water. Measurements were carried out using the Inductively Coupled Plasma-Optical Emission Spectroscopy (ICP-OES) (Optima 5300 DV, Perkin Elmer Inc., USA) based on the following parameter: autosampler model - AS-93 plus, sample flow rate $1.5 \mathrm{~mL} / \mathrm{min}$, plasma gas flow rate - Ar, $15 \mathrm{l} / \mathrm{min}$, auxiliary gas flow rate $-\mathrm{Ar}, 0.2 \mathrm{l} / \mathrm{min}$, nebulizer gas flow rate Ar, 0.65 1/min, back pressure $-75 \mathrm{kPa}$ and using both axial and radial plasma view.

\section{Statistical analysis}

All experiments were run in triplicates. Statistical analyses were conducted with the Statistical Analysis System (SAS) 9.1.3 software package. Analyses of variance were performed by ANOVA procedures. Significant differences $(p<0.05)$ were determined by least square means comparison. 


\section{Antioxidant content and antioxidant activity}

\section{Results and Discussion}

The results for antioxidant activity for $C$. caudatus herbal tea prepared from three different maturity stages are presented in Table 1. The highest TPC and TFC were obtained from C. caudatus herbal tea prepared from young leaves and the values of TPC and TFC ranged from 66.30 to $18.38 \mathrm{mg} \mathrm{GAE} / \mathrm{ml}$ herbal tea and 203.22 to $72.24 \mathrm{mg}$ GAE/ml herbal tea respectively. In line the declined in TPC and TFC values, FRAP values also significantly decreased as maturity of $C$. caudatus leaves used to prepare herbal tea progressed with the values ranging from 502.21 to $239.18 \mu \mathrm{M} \mathrm{TE} / \mathrm{ml}$ herbal tea. In contrast to FRAP values, the $\mathrm{IC}_{50}$ values of DPPH scavenging activity increased as maturity of $C$. caudatus leaves increased indicating that young leaves had strong antioxidant activity compared to mature and old leaves. The $\mathrm{IC}_{50}$ values of $C$. caudatus herbal tea prepared from young leaves, mature leaves and old leaves were $1055.37,1409.99$ and $2408.84 \mu \mathrm{g} / \mathrm{ml}$ respectively.

Table 1. Antioxidant activity in herbal tea prepared from C. caudatus leaves at different maturity stages. Values are expressed as mean \pm standard deviation. Means with different letters are significantly different $(\mathrm{p}<0.05)$

\begin{tabular}{|c|c|c|c|c|}
\hline \multirow[b]{2}{*}{$\begin{array}{l}\text { Herbal tea } \\
\text { sample }\end{array}$} & \multicolumn{4}{|c|}{ Assay } \\
\hline & $\begin{array}{c}\text { TPC } \\
\text { (mg GAE/ml } \\
\text { herbal tea) }\end{array}$ & $\begin{array}{c}\text { TFC } \\
\text { (mg QE/ml herbal } \\
\text { tea) }\end{array}$ & $\begin{array}{c}\text { FRAP } \\
(\mu M \text { TE/ml herbal } \\
\text { tea })\end{array}$ & $\begin{array}{l}\text { DPPH } \\
(\mu \mathrm{g} / \mathrm{ml})\end{array}$ \\
\hline Young leaves & $66.30 \pm 5.20^{\mathrm{a}}$ & $203.22 \pm 15.90^{\mathrm{a}}$ & $502.21 \pm 21.18^{\mathrm{a}}$ & $1055.37 \pm 42.38^{\mathrm{c}}$ \\
\hline Mature leaves & $36.55 \pm 2.77^{\mathrm{b}}$ & $124.55 \pm 6.22^{\mathrm{b}}$ & $332.00 \pm 8.81^{\mathrm{b}}$ & $1409.99 \pm 103.17^{b}$ \\
\hline Old leaves & $18.38 \pm 2.46^{\mathrm{c}}$ & $72.24 \pm 3.04^{\mathrm{c}}$ & $239.18 \pm 19.19^{c}$ & $2408.84 \pm 365.36^{\mathrm{a}}$ \\
\hline
\end{tabular}

In previous study of antioxidant activity by Mediani et al. [8] and Siddiqui et al. [17], they believed that, the reduction of antioxidant activity with the advanced maturity might be contributed to the conversion of phenolics and flavonoids to other secondary metabolites such as sugar by enzyme action. The declining of secondary metabolites in mature and old leaves reduced the ability of plant defense systems to neutralise the overproduction of ROS which stimulates by aging process, eventually cause senescence of plant tissues. This is supported by Sreelatha and Padma [18], where they observed the components of both the enzymatic and the non-enzymatic antioxidant system correlates well with oxidative stress during senescence and plant development. Another possible reason could be due to the stoppage of new biosynthesis of the secondary metabolites during maturation [19]. In contrast, most of these new biosynthesis are took place at the early stages of plant growth which provide highest phenolic and flavonoid compounds in young leaves to react with ROS produced [20]. The ROS will be chelated and disengaged by the antioxidant in young leaves from participating in the initiation of oxidative stress [17] where the ROS will be converted to a more stable products and the radical chain reaction will be terminated [21]. Therefore, this will provide protection of plant tissues against pests and disease [22].

Interrelationship between antioxidant activity (FRAP and DPPH) with TPC and TFC using Pearson's correlation coefficient are shown in Table 2 . The correlations between antioxidant activity with TPC and TFC are mainly due to their redox properties, hydrogen donors and singlet oxygen quenchers [18]. From the table, it revealed that FRAP had strong correlation with TPC and TFC with the values are $\mathrm{R}=0.9967$ and $\mathrm{R}=0.9980$ respectively while DPPH shows negative correlation with TPC $(R=-0.9224)$ and TFC $(R=-0.9288)$. This is in agreement with study by Baros et al. [23], where they highlighted the negative correlation between DPPH with TPC and TFC reflected that the sample with highest antioxidant content exhibited higher antioxidant activity and lower $\mathrm{IC}_{50}$ while sample with lowest antioxidant content exhibited lower antioxidant activity and higher $\mathrm{IC}_{50}$. Therefore, from correlations, phenolic and flavonoid compounds might contribute to the antioxidant activity in $C$. caudatus herbal tea prepared from leaves at three different maturity stages. According to Villa-Rodríguez et al. [24] phenolics and flavonoids had been devoted to their antioxidant activity due to their ability to reduce in vitro free radical formation and to 
scavenge free radicals which are responsible for inhibiting or preventing the deleterious consequences of oxidative stress [18].

Table 2. Pearson's correlation coefficient (R) between antioxidant activities of $C$. caudatus herbal tea prepared from leaves at different maturity stages

\begin{tabular}{ccc}
\hline & FRAP & DPPH \\
\hline TPC & $0.997 \pm 0.0018^{\mathrm{a}}$ & $-0.922 \pm 0.058^{\mathrm{a}}$ \\
TFC & $0.998 \pm 0.0024^{\mathrm{a}}$ & $-0.929 \pm 0.060^{\mathrm{a}}$ \\
\hline
\end{tabular}

\section{Colour}

Correlations between colour ( $\mathrm{L}^{*}$ - lightness, $\mathrm{a}^{*}$ - redness/greenness, $\mathrm{b}^{*}$ - yellowness/blueness, C - Chroma intensity, $\mathrm{h}^{\mathrm{o}}$ - hue angle tonalities) of $C$. caudatus herbal tea prepared from leaves at three different maturity stages with antioxidant activity were significantly strong (Table 3). As expected, C. caudatus herbal tea prepared from young leaves has significantly darker and yellower $\left(\mathrm{L}^{*}-37.39, \mathrm{~h}^{\circ}-97.46\right)$ than mature $\left(\mathrm{L}^{*}-36.48, \mathrm{~h}^{\circ}-98.04\right)$ and old leaves $\left(\mathrm{L}^{*}-35.26, \mathrm{~h}^{\circ}-99.45\right)$ since herbal tea prepared from young leaves has significantly highest antioxidant activity. It also showed that as maturity of $C$. caudatus leaves used to prepared herbal tea increased, the $\mathrm{C}$ value decreased significantly from 7.31 to 4.42 . From the results in Table 3, colour of $C$. caudatus herbal tea prepared from three different maturity stages give negative value for $\mathrm{a}^{*}$ and positive value for $\mathrm{b}^{*}$ which contributed to greenness and yellowness characteristic.

These findings is corroborated by Alves et al. [25] where they confirmed that index of antioxidant power had influenced by colour of the sample in which generally they found their light-coloured honeys have lower antioxidant activity while their dark-coloured honeys have huge amount of antioxidant activity. Similar results have been reported by others literatures, for examples Harbourne et al. [11] found that the meadowsweet extracts were significantly darker and redder than willow extract due to higher total phenolic content in meadowsweet extracts while Schwarz et al. [26] found that the increase of red and yellow tonalities of Sherry wines present an extraordinarily high antioxidant activity. Marete et al. [15] believed that, the dark colour of sample is possibly due to higher total phenolic content in the sample. Futhermore, Alvarez-Suarez [27] explained that the colour intensity of sample is related to pigments such as flavonoids and carotenoids. In fact, the increasing of the colour intensity seems to be related to an increase of the concentration of these compounds. Therefore, the results of this study seem to confirm that antioxidant activity is directly affecting $C$. caudatus herbal tea colour.

Table 3. The colour values of herbal tea prepared from C. caudatus leaves at different maturity stages. Values are expressed as mean \pm standard deviation. Means with different letters are significantly different $(\mathrm{p}<0.05)$

\begin{tabular}{lccccc}
\hline \multirow{2}{*}{$\begin{array}{c}\text { Herbal tea } \\
\text { sample }\end{array}$} & $\begin{array}{c}\text { Lightness } \\
\left(\mathbf{L}^{*}\right)\end{array}$ & $\begin{array}{c}\text { Greenness } \\
\left(\mathbf{a}^{*}\right)\end{array}$ & $\begin{array}{c}\text { Yellowness } \\
\left(\mathbf{b}^{*}\right)\end{array}$ & $\begin{array}{c}\text { Chroma } \\
(\mathbf{C})\end{array}$ & $\begin{array}{c}\text { Hue angle } \\
\left(\mathbf{h}^{\mathbf{0}}\right)\end{array}$ \\
\hline Young leaves & $35.25 \pm 0.20^{\mathrm{c}}$ & $-0.95 \pm 0.06^{\mathrm{c}}$ & $7.25 \pm 0.08^{\mathrm{a}}$ & $7.31 \pm 0.07^{\mathrm{a}}$ & $97.46 \pm 0.53^{\mathrm{b}}$ \\
Mature leaves & $36.48 \pm 0.15^{\mathrm{b}}$ & $-0.82 \pm 0.04^{\mathrm{b}}$ & $5.79 \pm 0.19^{\mathrm{b}}$ & $5.85 \pm 0.16^{\mathrm{b}}$ & $98.04 \pm 0.47^{\mathrm{b}}$ \\
Old leaves & $37.39 \pm 0.28^{\mathrm{a}}$ & $-0.73 \pm 0.03^{\mathrm{a}}$ & $4.36 \pm 0.17^{\mathrm{c}}$ & $4.42 \pm 0.18^{\mathrm{c}}$ & $99.45 \pm 0.62^{\mathrm{a}}$ \\
\hline
\end{tabular}

\section{Mineral content}

Most people believed that consumption of herbal tea can enhance human health. Hence, determination of mineral content is also important in herbal tea due to their responsibilities in providing medicinal and nutritional properties. According to Tokalıoğlu [28], the quantitative estimation of various mineral content is important in determining the effectiveness of the medicinal plants used in herbal tea preparation in treating various diseases and also to 
understand their pharmacological action. Therefore this study involved the evaluation of some important macroelements $(\mathrm{Ca}, \mathrm{K}, \mathrm{Mg}$ and $\mathrm{Na}$ ) and microelements $(\mathrm{Ag}, \mathrm{Al}, \mathrm{Ba}, \mathrm{Cd}, \mathrm{Cr}, \mathrm{Cu}, \mathrm{Fe}, \mathrm{Pb}$ and $\mathrm{Zn}$ ) in C. caudatus herbal tea prepared from three different maturity stages and results are shown in Table 4. Interestingly, among all the $C$. caudatus herbal tea samples, $C$. caudatus herbal tea prepared from old leaves had significantly higher minerals like $\mathrm{Ca}, \mathrm{Mg}, \mathrm{Na}$ (macroelements) and $\mathrm{Ba}, \mathrm{Cd}, \mathrm{Cr}, \mathrm{Cu}, \mathrm{Mn}$ (microelements) compared to mature and young leaves. However, for $\mathrm{K}$ (macroelements) $\mathrm{Ag}, \mathrm{Al}, \mathrm{Fe}, \mathrm{Pb}, \mathrm{Zn}$ (microelements) there were no significant difference among samples.

Table 4. Mineral content of Cosmos caudatus herbal tea sample prepared from leaves at different maturity stages. Values are expressed as mean \pm standard deviation. Means with different letters are significantly different $(\mathrm{p}<0.05)$

\begin{tabular}{|c|c|c|c|c|}
\hline \multicolumn{2}{|c|}{$\begin{array}{c}\text { Mineral } \\
(\mu \mathrm{g} / \mathrm{ml} \text { of tea })\end{array}$} & \multirow{2}{*}{$\begin{array}{c}\begin{array}{c}\text { Herbal tea prepared } \\
\text { from young leaves }\end{array} \\
13.5958 \pm 0.9019^{\mathrm{c}}\end{array}$} & \multirow{2}{*}{$\begin{array}{c}\begin{array}{c}\text { Herbal tea prepared } \\
\text { from mature leaves }\end{array} \\
31.4583 \pm 1.0670^{\mathrm{b}}\end{array}$} & \multirow{2}{*}{$\begin{array}{c}\begin{array}{c}\text { Herbal tea prepared } \\
\text { from old leaves }\end{array} \\
51.0042 \pm 4.6142^{\mathrm{a}}\end{array}$} \\
\hline 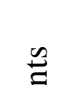 & $\mathrm{Ca}$ & & & \\
\hline$\frac{\tilde{0}}{0}$ & $\mathrm{~K}$ & $94.5375 \pm 1.7852^{\mathrm{a}}$ & $96.4208 \pm 9.1021^{\mathrm{a}}$ & $98.6583 \pm 5.1247^{\mathrm{a}}$ \\
\hline : & $\mathrm{Mg}$ & $8.3117 \pm 0.2564^{\mathrm{b}}$ & $9.3179 \pm 0.2905^{\mathrm{b}}$ & $13.6108 \pm 1.0186^{\mathrm{a}}$ \\
\hline & $\mathrm{Na}$ & $0.5463 \pm 0.0055^{\mathrm{c}}$ & $0.6070 \pm 0.0343^{\mathrm{b}}$ & $0.6830 \pm 0.0253^{\mathrm{a}}$ \\
\hline \multirow{10}{*}{ 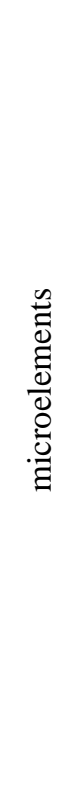 } & $\mathrm{Ag}$ & $0.0035 \pm 0.0006^{\mathrm{a}}$ & $0.0035 \pm 0.0001^{\mathrm{a}}$ & $0.0045 \pm 0.0007^{\mathrm{a}}$ \\
\hline & $\mathrm{Al}$ & $0.0310 \pm 0.0035^{\mathrm{a}}$ & $0.0311 \pm 0.0024^{a}$ & $0.0318 \pm 0.0010^{a}$ \\
\hline & $\mathrm{Ba}$ & $0.0052 \pm 0.0003^{\mathrm{c}}$ & $0.0076 \pm 0.0002^{b}$ & $0.0149 \pm 0.0021^{\mathrm{a}}$ \\
\hline & $\mathrm{Cd}$ & $0.0073 \pm 0.0006^{\mathrm{b}}$ & $0.0070 \pm 0.0010^{\mathrm{b}}$ & $0.0011 \pm 0.0020^{\mathrm{a}}$ \\
\hline & $\mathrm{Cr}$ & $0.0321 \pm 0.0031^{\mathrm{b}}$ & $0.0394 \pm 0.0044^{\mathrm{ab}}$ & $0.0433 \pm 0.0036^{\mathrm{a}}$ \\
\hline & $\mathrm{Cu}$ & $0.0313 \pm 0.0024^{b}$ & $0.0319 \pm 0.0004^{\mathrm{b}}$ & $0.0388 \pm 0.0036^{\mathrm{a}}$ \\
\hline & $\mathrm{Fe}$ & $0.0458 \pm 0.0007^{\mathrm{a}}$ & $0.0454 \pm 0.0044^{a}$ & $0.0500 \pm 0.0022^{\mathrm{a}}$ \\
\hline & $\mathrm{Mn}$ & $0.0310 \pm 0.0018^{\mathrm{b}}$ & $0.0675 \pm 0.0012^{\mathrm{a}}$ & $0.0730 \pm 0.0046^{\mathrm{a}}$ \\
\hline & $\mathrm{Pb}$ & $0.0012 \pm 0.0006^{a}$ & $0.0011 \pm 0.0012^{a}$ & $0.0012 \pm 0.0006^{a}$ \\
\hline & $\mathrm{Zn}$ & $0.0534 \pm 0.0027^{\mathrm{a}}$ & $0.0533 \pm 0.0083^{a}$ & $0.0534 \pm 0.0012^{\mathrm{a}}$ \\
\hline
\end{tabular}

This result might be due to the location of old leaves in which they are located near to the roots, where generally, the roots contain the highest levels of elements followed by vegetative tissues [28]. This is because the plants readily assimilate the elements through the roots, which will dissolved in water and occur in ionic forms [29]. Another possible reason is that, the growth of tissues plants also profoundly influence the minerals absorption, in which as tissues mature, volume of water uptake by cell increased which may dilute the internal concentration of minerals, thus increase absorption activity [30]. This is supported by Flowers and Yeo [31] where they reported that the volume of mature cell increase with time, providing mineral-storage capacity at constant concentration. However, some authors believed that, the decrement in concentration of mineral content might be directly related to 
the accumulation of antioxidant content in plants. Sulaiman et al. [32] reported that an imbalance of minerals in plants would change the content of flavonoids, a proven antioxidant compounds. For example, as found by some researchers, the deficiency of several minerals such as $\mathrm{K}, \mathrm{Mg}$, and $\mathrm{Mn}$ induced the flavonoid accumulation in plants $[5,32]$. Therefore, this study revealed that, as maturity of $C$. caudatus leaves used to prepared herbal tea increased, it may increase some of mineral content due to decrement in antioxidant activity.

Table 5. Dietary Reference Intake (DRI) and percentage contribution of herbal tea prepared from C. caudatus leaves prepared from different maturity stages per $200 \mathrm{ml}$ in a day

\begin{tabular}{|c|c|c|c|}
\hline \multicolumn{2}{|c|}{ Mineral } & \multirow{2}{*}{$\begin{array}{c}\text { Recommended Dietary Allowances, } \\
\text { RDA / Adequate Intake, AI } \\
(\mathbf{1 9}-\mathbf{5 0} \text { years old })(\mathbf{m g})\end{array}$} & \multirow{2}{*}{$\begin{array}{c}\text { Percentage contribution of } \boldsymbol{C} \text {. } \\
\text { caudatus herbal tea per } 200 \mathbf{~ m l} \text { in } \\
\text { a day }(\%) \\
\text { Men }=0.22-1.02 \\
\text { Women }=0.22-1.02\end{array}$} \\
\hline$\stackrel{\sim}{=}$ & $\mathrm{Ca}$ & & \\
\hline है & $\mathrm{K}$ & $\begin{array}{c}\text { Men }=4700 \\
\text { Women }=4700\end{array}$ & $\begin{array}{c}\text { Men }=0.40-0.42 \\
\text { Women }=0.40-0.42\end{array}$ \\
\hline : & $\mathrm{Mg}$ & $\begin{array}{c}\text { Men }=400 \\
\text { Women }=310\end{array}$ & $\begin{array}{c}\text { Men }=0.41-0.68 \\
\text { Women }=0.54-0.88\end{array}$ \\
\hline & $\mathrm{Na}$ & $\begin{array}{c}\text { Men }=1500 \\
\text { Women }=1500\end{array}$ & $\begin{array}{c}\text { Men }=0.007-0.009 \\
\text { Women }=0.007-0.009\end{array}$ \\
\hline \multirow{10}{*}{ 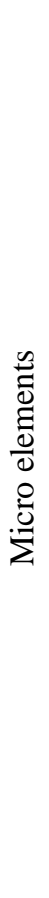 } & $\mathrm{Ag}$ & $\begin{array}{c}\text { Men = na } \\
\text { Women = na }\end{array}$ & $\begin{array}{c}\text { Men = na } \\
\text { Women = na }\end{array}$ \\
\hline & $\mathrm{Al}$ & $\begin{array}{c}\text { Men = na } \\
\text { Women = na }\end{array}$ & $\begin{array}{c}\text { Men = na } \\
\text { Women = na }\end{array}$ \\
\hline & $\mathrm{Ba}$ & $\begin{array}{c}\text { Men = na } \\
\text { Women = na }\end{array}$ & $\begin{array}{c}\text { Men = na } \\
\text { Women = na }\end{array}$ \\
\hline & $\mathrm{Cd}$ & $\begin{array}{c}\text { Men = na } \\
\text { Women = na }\end{array}$ & $\begin{array}{c}\text { Men = na } \\
\text { Women = na }\end{array}$ \\
\hline & $\mathrm{Cr}$ & $\begin{array}{c}\text { Men }=35^{*} \\
\text { Women }=25^{*}\end{array}$ & $\begin{array}{c}\text { Men }=18.29-24.86 \\
\text { Women }=25.60-34.80\end{array}$ \\
\hline & $\mathrm{Cu}$ & $\begin{array}{c}\text { Men }=900 \\
\text { Women }=900\end{array}$ & $\begin{array}{c}\text { Men }=0.70-0.87 \\
\text { Women }=0.70-0.87\end{array}$ \\
\hline & $\mathrm{Fe}$ & $\begin{array}{c}\text { Men }=8 \\
\text { Women }=18\end{array}$ & $\begin{array}{c}\text { Men }=0.12-0.13 \\
\text { Women }=0.05-0.06\end{array}$ \\
\hline & $\mathrm{Mn}$ & $\begin{array}{c}\text { Men }=2.3^{*} \\
\text { Women }=1.8^{*}\end{array}$ & $\begin{array}{c}\text { Men }=0.27-0.63 \\
\text { Women }=0.34-0.81\end{array}$ \\
\hline & $\mathrm{Pb}$ & $\begin{array}{c}\text { Men = na } \\
\text { Women = na }\end{array}$ & $\begin{array}{c}\text { Men = na } \\
\text { Women = na }\end{array}$ \\
\hline & $\mathrm{Zn}$ & $\begin{array}{c}\text { Men }=11 \\
\text { Women }=8\end{array}$ & $\begin{array}{c}\text { Men }=0.10 \\
\text { Women }=0.13\end{array}$ \\
\hline
\end{tabular}

Note : Ordinary type represents source from [33] while bold type represents source from [34], Italic type represents the unit in $\mu \mathrm{g}$, Value with asterisk $(*)$ represent Adequate Intake $(\mathrm{AI})$, na = not available

Macroelements $(\mathrm{Ca}, \mathrm{K}, \mathrm{Mg}$ and $\mathrm{Na}$ ) were detected in highest concentration in all three C. caudatus herbal tea samples compared to microelements. This is because bioavailability of the elements depends on the bonding with the constituents of the soil [29]. In addition, as confirmed by Devlin and Witham [30] that $\mathrm{Ca}, \mathrm{K}, \mathrm{Mg}$ and $\mathrm{Na}$ are major elements that contributed to the plant growth. Nevertheless, the contribution of mineral content in herbal tea 
on the average dietary intake must be taken into consideration. The consumption rate of $C$. caudatus herbal tea should be under strict control and should not exceed Dietary Reference Intake (DRI) since exceeding some of these minerals might cause toxicity. Based on the results obtained, none of the macro and microelements was exceed the DRI based on Recommended Dietary Allowances (RDA) or Adequate Intake (AI) as in Table 5 [33,34]. Besides, the toxic elements such as $\mathrm{Ag}, \mathrm{Al}, \mathrm{Ba}, \mathrm{Cd}$ and $\mathrm{Pb}$ were detected in low concentration. Therefore, depending on the mineral content in $C$. caudatus herbal tea prepared from three different maturity stages, these herbal tea may be a good source of essential minerals.

\section{Conclusion}

In conclusion, usage of $C$. caudatus leaves for tea production at different maturity stages, affects the antioxidant activity, colour and mineral content of herbal tea. C. caudatus herbal tea prepared from young leaves possessed significantly strong antioxidant activity compared to mature and old leaves in all assays tested. Strong positive Pearson's correlations between reducing power with TPC and TFC, and strong negative Pearson's correlation between DPPH scavenging activity with TPC and TFC showed that phenolic and flavonoid compounds are major contributions to the antioxidant activity in $C$. caudatus herbal tea at all maturity stages studied. The darker colour of C. caudatus herbal tea prepared from young leaves compared to other two leaves relates to the high phenolic and flavonoid content in young leaves. In contrast, C. caudatus herbal tea prepared from old leaves exhibited significantly high in $\mathrm{Ca}, \mathrm{Mg}, \mathrm{Na}$ for macro elements and $\mathrm{Ba}, \mathrm{Cd}, \mathrm{Cr}, \mathrm{Cu} \mathrm{Mn}$ for microelements compared to mature and young leaves.

\section{Acknowledgement}

The authors would like to thank Universiti Teknologi MARA (UiTM) for their technical and financial support.

\section{References}

1. Quispe, C., Viveros-Valdez, E. and Schmeda-Hirschmann, G. (2012). Phenolic constituents of the chilean herbal tea Fabiana imbricata R. et P. Plant Foods for Human Nutrition, 67(3): 242-246.

2. Zhao, J., Deng, J. W., Chen, Y. W. and Li, S. P. (2013). Advanced phytochemical analysis of herbal tea in China. Journal of Chromatography A, 1313: 2 - 23.

3. Horžić, D., Komes, D., Belščak, A., Ganić, K. K., Iveković, D. and Karlović, D. (2009). The composition of polyphenols and methylxanthines in teas and herbal infusions. Food Chemistry, 115(2): $441-448$.

4. Tschiggerl, C. and Bucar, F. (2012). The volatile fraction of herbal teas. Phytochemistry Reviews, 11(2-3): 245 -254 .

5. Whittaker, A., Vazzana, C., Vecchio, V. and Benedettelli, S. (2009). Evaluation of direct and indirect effects of flavonoids, mineral elements and dry weight on antiradical scavenging activity in leaf material of field-grown Trifolium pratense cultivars using path analysis. Field Crops Research, 113: 1-11.

6. Amna, O. F., Nooraain, H., Noriham, A., Azizah, A. H. and Husna, R. N. (2013). Acute and oral subacute toxicity study of ethanolic extract of Cosmos caudatus leaf in sprague dawley rats. International Journal of Bioscience, Biochemistry and Bioinformatics, 3(4): 301 - 305.

7. Shui, G., Leong, L. P. and Wong, S. P. (2005). Rapid screening and characterisation of antioxidants of Cosmos caudatus using liquid chromatography coupled with mass spectrometry. Journal of Chromatography B, 827(1): $127-138$.

8. Mediani, A., Abas, F., Ping, T. C., Khatib, A. and Lajis, N. H. (2012). Influence of growth stage and season on the antioxidant constituents of Cosmos caudatus. Plant Foods for Human Nutrition, 67(4): $344-350$.

9. Rehecho, S., Hidalgo, O., Cirano, M. G. D., Navarro, I., Astiasarán, I., Ansorena, D., Yolanda, R. and Isabel, M. (2011). Chemical composition, mineral content and antioxidant activity of Verbena officinalis L . LWT Food Science Technology, 44(4): 875 - 882.

10. Gião, M. S., Pereira, C. I., Fonseca, S. C., Pintado, M. E. and Malcata, F. X. (2009). Effect of particle size upon the extent of extraction of antioxidant power fom the plants Agrimonia eupatoria, Salvia sp. and Satureja montana. Food Chemistry, 117(3): $412-416$.

11. Harbourne, N., Marete, E., Jacquier, J. C. and O'Riordan, D. (2009). Effect of drying methods on the phenolic constituents of meadowsweet (Filipendula ulmaria) and willow (Salix alba). LWT - Food Science Technology, 42(9): $1468-1473$. 
12. Singh, V., Guizani, N., Essa, M. M., Hakkim, F. L and Rahman, M. S. (2012). Comparative analysis of total phenolics, flavonoid content and antioxidant profile of different date varieties (Phoenix dactylifera $L$.) from Sultanate of Oman. International Food Research Journal, 19(3): 1063 - 1070.

13. Deetae, P., Parichanon, P., Trakunleewatthana, P., Chanseetis, C. and Lertsiri, S. (2012). Antioxidant and antiglycation properties of thai herbal teas in comparison with conventional teas. Food Chemistry, 133(3): 953 959.

14. Nuengchamnong, N. and Ingkaninan, K. (2010). On-line HPLC-MS-DPPH assay for the analysis of phenolic antioxidant compounds in fruit wine: Antidesma thwaitesianum Muell. Food Chemistry, 118(1): 147 - 152.

15. Marete, E. N., Jacquier, J. C. and O'Riordan, D. (2009). Effects of extraction temperature on the phenolic and parthenolide contents, and colour of aqueous feverfew (Tanacetum parthenium) extracts. Food Chemistry, 117(2): $226-231$.

16. Pytlakowska, K., Kita, A., Janoska, P., Połowniak, M. and Kozik, V. (2012). Multi-element analysis of mineral and trace elements in medicinal herbs and their infusions. Food Chemistry, 135(2): $494-501$.

17. Siddiqui, M.W., Momin, C. M., Acharya, P., Kabir, J., Debnath, M. K. and Dhua, R. S. (2012). Dynamics of changes in bioactive molecules and antioxidant potential of capsicum chinense Jacq. cv. Habanero at nine maturity stages. Acta Physiologiae Plantarum 35(4): 1141 - 1148.

18. Sreelatha, S. and Padma, P. R. (2009). Antioxidant activity and total phenolic content of Moringa oleifera leaves in two stages of maturity. Plant Foods for Human Nutrition, 64(4): 303 - 311.

19. Fawole, O. A. and Opara, U. L. (2013). Changes in physical properties, chemical and elemental composition and antioxidant capacity of pomegranate (cv. Ruby) fruit at five maturity stages. Science Horticulture (Amsterdam)., 150: 37 - 46.

20. Menichini, F., Loizzo, M. R., Bonesi, M., Conforti, F., Luca, D. D., Statti, G. A., Cindio, B. D., Menichini, F. and Tundis, R. (2011). Phytochemical profile, antioxidant, anti-inflammatory and hypoglycemic potential of hydroalcoholic extracts from Citrus medica L. cv Diamante flowers, leaves and fruits at two maturity stages. Food Chemistry and Toxicology, 49(7): $1549-1555$.

21. Oh, J., Jo, H., Cho, A. R., Kim, S.-J. and Han, J. (2013). Antioxidant and antimicrobial activities of various leafy herbal teas. Food Control, 31(2): $403-409$.

22. Shuib, N. H., Shaari, K., Khatib, A., Kneer, R., Zareen, S., Raof, S. M., Lajis, N. H. and Neto, V. (2011). Discrimination of young and mature leaves of Melicope ptelefolia using ${ }^{1} \mathrm{H}$ NMR and multivariate data analysis. Food Chemistry, 126(2): 640 - 645.

23. Barros, L., Queiro, B., Ferreira, I. C. F. R. and Baptista, P. (2007). Total phenols, ascorbic acid, $\beta$-carotene and lycopene in portuguese wild edible mushrooms and their antioxidant activities. Food Chemistry, 103: 413- 419.

24. Villa-Rodríguez, J. A., Molina-Corral, F. J., Ayala-Zavala, J. F., Olivas, G. I. and González-Aguilar, G. A. (2011). Effect of maturity stage on the content of fatty acids and antioxidant activity of 'hass' avocado. Food Research International, 44(5): 1231 - 1237.

25. Alves, A., Ramos, A., Gonçalves, M. M., Bernardo, M. and Mendes, B. J. (2013). Antioxidant Activity, quality parameters and mineral content of portuguese monofloral honeys. Journal of Food Composition and Analysis, 30(2): $130-138$.

26. Schwarz, M., Rodríguez, M. C., Guillén, D. A. and Barroso. C. G. (2012). Evolution of the colour, antioxidant activity and polyphenols in unusually aged sherry wines. Food Chemistry, 133: $271-276$.

27. Alvarez-Suarez, J. M., Tulipani, S., Díaz, D., Estevez, Y., Romandini, S., Giampieri, F., Damiani, E., Astolfi, P., Bompadre, S. and Battino, M. (2010). Antioxidant and antimicrobial capacity of several monofloral cuban honeys and their correlation with color, polyphenol content and other chemical compounds. Food Chemistry Toxicology, 48(8-9): 2490 - 2499.

28. Tokalıoglu, Ş. (2012). Determination of trace elements in commonly consumed medicinal herbs by ICP-MS and multivariate analysis. Food Chemisty, 134(4): $2504-2508$.

29. Başgel, S. and Erdemoğlu, S. B. (2006). Determination of mineral and trace elements in some medicinal herbs and their infusions consumed in Turkey. Science of Total Environment, 359(1-3): $82-89$.

30. Devlin, R. M. and Witham, F. H. (1983). Plant physiology. Willard Grant Press, Boston, pp. 96 -129.

31. Flowers, T. J. and Yeo, A. R. (1992). Tertiary level biology: solute transport in plants. Thomas Press, New Delhi, India, pp. 137. 
32. Sulaiman, S. F., Sajak, A. A. B., Ooi, K. L. and Seow, E. M. (2011). Effect of solvents in extracting polyphenols and antioxidants of selected raw vegetables. Journal of Food Composition and Analysis, 24(4-5): $506-515$.

33. The National Academies. Dietary reference intakes: elements dietary reference intakes: elements. (2001). Downloaded from www.nap.edu.

34. Ministry of Health Malaysia. Recommended nutrient intakes for Malaysia: A Report of the technical working group on nutritional guidelines. (2005). Downloaded from http://www.moh.gov.my/images/gallery/ rni/insert.pdf. 